for three weeks, then stopped, and two dars later all the meningeal snmptoms commenced again-headache, donble Kernig, some temperature; the cerebro-spinal fluid was again under tension. Repeated lumbar punctures were performed, and vacoines were commenced. With rewarl to the question of varoine treatment, he must honestly confess he would not like to say it hat any bearing on the result: if the patient harl heen given vaceines and no lumbar punctures perhaps the result would not have been so good. The question of the different forms of meningitis would he a very useful discussion for this Suciety at a future date.

\title{
THE FRENCH SOCIETY OF LARYNGOLOGY, OTOLOGY AND RHINOLOGY.
}

\author{
$111 y, 1911$. \\ President: E. Escat (Toulou-e).

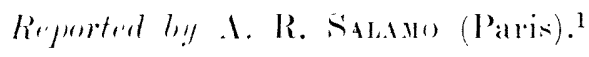

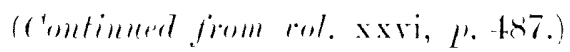

\section{Classification of Deafness.}

By Dr. J. Morintí.

Multiplicity and lack of uniformity of areoumetric methods learling to confusion, Molini, proposes to take hearine power for conversation ats a rriterion for the estimation of deafness. Adopting this principle, he arranges the varions forms of deafness in four categoriess. differentiated ly the following characteristies:

(1) Although having a more or less appreciable alteration in hearing, the subjects of this class are able to participate in ordinary conversation, attend functions, theidres, church, eite. Obliged to maintain a forest attention, they miss some words and oftentimes reguire them repeated: still they can leal an ordinary life and fulfil most pullic duties.

(2) Patients who no longer hear ordinary conversation, and can only (onverse tite it tite. Gatherings and conferences are devoid of interest to them and they alosent themselves from choice. Sometimes, however, they are able to appreciate music. They are only competent to take up' ocrupations involving but littie responsibility.

(3) This category comprises those who only hear loul anversation, or shonted worls near the ear. These patients are unfit for all public employment.

(4) Here are incluled those asses where the auditory apparatus has been completely destroyed. The subjects of this wroup are compellerl to resort to writing or gestures to communirate with their fellows.

Molinic pointed out that this clitssification was not entirely arlitrary and artificial, but that it conformed to some ordinary well-defined types, and in some meisure to the stages of deafness. The information

1 Translated from Les Archices Internationnles, tome xxxi, supplement to Xo. :3. 
furnished ly this method of classifying the reaf would, if it were adopted, enable one to form an opinion, at least approximately of leafness in the sulljects examined, which is impossible with methods of estimation at present in vogue.

\title{
Lactic Acid Ferment in Rhinology.
}

By Dr. Kennifi (Paris).

The author has employed Dr. Boncard's preparation in ozæna and has hat good results. In ordinary rininitis during the early stage he has also experienced excellent results. A little powder used is snuff in the initial stage of coryza causes its disappearance.

\section{Re-education of Hearing by Zund-Burguet's Method.}

\author{
By I)r. A. Raoult (Nathey).
}

The author reported six cases of otoselerosis marketlly improved hy the alove method. 'These patients attended fifty courses of the treatment The method comprises: (1) Re-education for sounds from the first to the. fifth octave, which may he graduated at pleasure: (2) stimulation of tartile sensibility. inclueed by the passage of Faradic currents in the microphonic circuit. The duration of the setures varies according to the nervous state of the patient ant the intensity of the sound given. Passage of the indured current gives rise to a sensation of tickling in the ear : this is not noticed during the first siones, especially in the rase of old sclerotics. These at first experience a feeling of intense vilnation, which wires place to true tickling at about the tenth or fifteenth sitting. From a stuly of these facts we mas infer that re-education by Zumb-Burguet's method causes (1) molilisation and massage of the conductive media : (2) stimulation of the preceptive aulitory mechanism. In fact the patients frequently perceive cracking somds and sometimes louzzing in the fars between the sifanres. Stimulation of the nervous system acts on the receptive anditory mechanism, the sensory and vaso-motor nervous $\because$ stems. Sounds become progressively perceptible. The sensation of tickling gradually reappears. Iastly, after each sitting the patients experience a sensation of warmth in the ear, and often in the whole of the head. Ihe improvements observed in the patients continue to manifest themselves even when treatment is discontinnerl, and Helsmortel, of Antwerp, has noted their persistence in patients treated a rear previously.

\section{Some Considerations on the Zund-Burguet Method for the Treatment of Certain Forms of Deafness.}

\author{
By Dr. Roure (Valeneia).
}

Dr. Chavannf (Isyons) asked if the method of re-educition had not for its object the reawakening of function. He would be pleased to be acquainted in detail with Zund-Burguet's apparatus.

Dr. JACQUes (Nancy) asked what was the remote result of the method.

Dr. Luc (Paris) wonlered whether improvement would not have vecurred without treatment.

Dr. Raovlt (Nancy) remarked that the manufacture of the apparatus 
was secret, but that does not detract from any of its merits. To Dr. Lue's criticism. he answered that his patients harl been affected for the past two vears.

Dr. Bonan (Brest) inquired why this method was designated " tht" method of re-education." "The term, he thought, was barly chosen.

Dr. Gaver (Dijon) had had two cases treated by this method, with not very brilliant results. It ought to he tried on thoroughly trpical sclerotic cases.

Dr. Roune (Valencia) replied that the results obtainet listed several months. He hail a solerotic patient of twelve vears stamling who hats remained much improved for sereral months past.

Dr. Trítrôp (Antwerp) insisted that the distinction between arthesive otitis and otosclerosis should be rearly establisherl, the former recovering minler other methods of treatment.

\section{A Special Form of Mastoid Infection in Chronic Infantile Otorrhœa: "Mastoiditis Nigra."}

By Dr. Brindeu, (Borleaux).

In this communication, hased on 16 catses out of 1200 operater on, the author arrives at the following conclisions:

(1) There are some infections of the mastoid process chatracterised lig diffuse cellulitis, blackish in colour, which he designates "mastoiditis nierra."

(2) This atfection is peculiar to infancy, and is met with almost exchusively in foetil otorrhoea of long standing.

(3) The lark coloration loes not exclute lesions which one is areustome l to meet with in chronic otorrhoea.

(4) Mastoiditis nigra is a diffuse osteomyelitis almost alwars necessitating the radical mastoid operation.

(5) Events run a normial course after operation.

(6) For vear's after recoverr, blackish bullæ, due to separation of the epithelial lining hy a dark-coloured fluid, are sometimes met with on the wallss of the operaiter cavity.

(7) The pathorenesis of this affection is still unknown. A cultivation taken from morhid tissue during the operations was mattended with any result.

\section{Conservative Treatment of Chronic Suppuration of the Middle Ear, with or without Lesions of the Labyrinth Wall.}

By Dr. Trítrôp (Antwerp).

From statisties during the past ten years the anthor observed that major operations did not exceed 5 per cent of the cases treated, and in one series of ases fell below 2 per cent. This treatment therefore deserves consideration. In Germany, scheibbe and Siebenmann have experienced similar results. Chronic otorrhoea of ten, fifteen, or even twenty years standing is amenable to treatment by asepsis and antisepsis. Localised carions processes of the labyrinth are not an exception to these results. Trittôp especially extols preparations capable of conveying oxygen, e. $y$. perhydrol, perganol, alkaline perborates, peroxide of zinc. Oxygen induces elimination, and augments tissue vitality. Amongst antiseptics, mereurial salts, formalin and its derivative aniodol, silver 
salts, especially those of an organic nature, as protargol, argryol. etc. c'lnomice ar.il, borie, lartic, pieric and ionline each has its indications, which are lealrnt hy experience.

\title{
Routes of Access to the Cavernous Sinus.
}

By Dr. Bourguet ('Tuulouse).

After having mentioned the methods of Voss. Lac and Tavenier, the wuthor showed by the aid of drawings that the best route for rearluing the sinns ronsisted, after a para-nasal incision, in removing the nasal frreess of the superior maxilla, the whole of the imner wall of the orlit. with the corresponting ethmoil and part of the nasal septum, ancl, after penetrating the sphenoidal simus, in removing the inner wall of the "avernous simus with a chisel. This is a direct way of access, which affords ample room and does not distigure the patient."

Dr. Lafite-T)upont (Bordeaux) hat onerated on the cavernoms inus by the unilateral trans-maxillary route and realised the difficulties of getting at the sinus ly this method.

\section{A Case of Cerebellar Abscess; Operation; Recovery.}

\author{
By J. Labouré (Amiens).
}

A patient, aged twentr-three, suffering from chronic otorrhasi. smldenly developed vertigo, vomiting and severe hearlache. In spite of introtomy the symptoms persisted with spontaneous nystagmus towaris. the corresponding side. These phenomena were attributed to the wrebellum, but eximination of the intermal eatr revealed labrinth involvement as well. During the radical operation the curette penetriterl mto at cerebellar abscess and clinched the diagnosis. The labyrinth wats not toucherl, as there appeared to be no connertion between it and the ihscess. Recovery followed in a month.

\section{Determination of the Upper Tone-limit by Aerial and Bone- conduction, by means of Struycken's Monochord.}

\author{
By Dr. (havanne (Turoms).
}

'The monochort recently constructed under the direction of Strurcken is really the hest instrument for estimating the upper tone-linit of hearing hy airial conduction. Moreover it enables one to estimate the limit by bone-conduction ; for contrary to classical opinion, the hivhest notes are perfectly heard by bone-conduction. Normally the upper. usseous limit is alwavs higher than the airval. In commencing sclerensis me finds a raised limit for both forms of conduction, but especially in the catse of osseous.

\section{Retro-Auricular Abscess following a Meatal Furuncle in a Patient prexiously Operated on for Mastoiditis.}

By Dr. F. Chavanne (Lyons).

In February, 1890, a child, aged seven veurs, was operated on for atute mastoiditis and recovered normally. A vear later, after a boil of the meatus on the same side, suppuration of the middle ear developed. 
with a retro-auricular alsscess the size of a hen s egg, occupying the old operated cavity. Recovery followed opening and evacuation of the aliscess.

\section{The Complications of Adenoidectomy.}

\section{By Drs. Grossard and Kaufmann. ${ }^{1}$}

Dr. Bonarn (Brest) said that we could a roid trammatic complications by good illumination, general anæsthesia and skilful use of instruments. $\dot{H}$ e considered it an exingeration to say that general anæsthesia was not necessary in patients under five years of age.

Dr. Chavaune (Val-de-Grace) held that adenoilectomy was not the minor operation that people thought. It was most essential to watch one's patients for several days after the operation. The patient ought to be confined to his room.

Dr. Castex (Paris) showed a child who was an example of the complications following adenoidectomy. This child harl a diaphragm which absolutely impeded breathing by the month.

Dr. Mignon (Nice) cited the case of a child operated on by a nonspecialist. There was copions hæmorthage and fever. On examining the pat ient he found a portion of adenoid tissue in the pharynx.

Dr. Jacques (Nancy) hal been estruck at the limit of five years, fixed for general anæsthesia. Post-operative torticollis was a frequent complication. He had never been greatly alarmed concerning the fall of arlenoid regetations into the larrnx. Exception must be taken to the tendenc $y$ of considering arlemoilectomy a benign operation.

Dr. Broecknaert (Ghent) found suppurative ot it is to be commoner after adenotomy than was generally supposed. The importance of the operation must he insisted on.

Dr. Grossard (Paris), in reply, said that it was purely a personal "finion to consider an anæsthetic unnecessary under five years of ane. It was simply a matter of discretion.

\section{A Case of Cerebral Abscess of Otitic Origin Operated on whilst in a Comatose Condition; Recovery.}

By Dr. Barr (Nices).

A woman, aged fifty-six, wats brought to the Nice Hospital deeply comatose. Old-standing double suppurative otitis, with cessation of discharge on the right side. Left hemiplegia, right facial paralysis and paraphasia, the only physical signs present at the time, enabled the author to diagnose an abscess of the right temporal lobe. The absceswas operated on during deep coma, aided by chloroform. The patient came round during the operation. Complete recovery followed. 'Thicase afforded the opportunity for reviewing the symptomatology of cerebral abscess. Embracing the very practical symptomatological livision of Bergman, the author showed that in taking into consideration the symptoms of cerebral compression, the endo-cranial tumour indicater? hy them is a purulent one, that is an abscess, if symptoms of general sippuration accompany it. It then remains to discover its situation. Localising signs afford help. They may be rare and obscure, especiall! when the abscess is on the right side (Moure). They are motor anit sensory paralyses, aphasia, associated with psychic troubles, fixed headache and a peculiar febrile state.

1 See Jovrn. of Laringol., Rhinol., and Otol., July, 1911, p. 383. 


\title{
Contribution to the Treatment of Ozæna by Nasal Respiratory Re-education.
}

\author{
By Dr. Robert Foy (Paris).
}

The author related the results of his researches carried out during the past two years hoth in Lermovez's practice and at Mahu's clinic. "The treatment was described and the necessary apparatus exhibited. The author remarked that ozænatous subjects breathe inadequately and most often not at all by the nose. By nasal respiratory re-education with compressed air he noticed that from the day patients breathe freely and continuously by the nose, the odour and crusts permanently disappear, in spite of entirely discarding lavage. Sometimes after treatment a discharge of whitish mucus persists, such as one meets with in many non-ozænatous persons (catarrh). In thirty-two advanced cases of ozæna there were twenty-two recoveries and ten failures. In the case of the latter nasal respiration could not be re-established owing to the patients being too young and not possessing the necessary intelligence. Crusts and foetor are only the results of diminution or absence of nasal breathing, the necessary physiological stimulus to the mucous membranes of the upper air-passages for the carrving on of their manifold functions, this functional trouble always being seconlary to, or associaterl with, a chronic mucopurulent catarrh, specific or not.

Dr. Brinde (Bordeaux) asked what grounds one hat for saying that the ozenatous patients breathed harly through the nose. Did not Foy's method consist solely of a form of massage of the mucosa? He hal tried the treatment of re-eilucation. but the patients had not been cured of their izæna. The general health was improved. but ozæna persisted. Had Foy carried ont his treatment without acompanying it with a topical application?

Dr. Moure (Bordeaux) said that ozæna oecurrel in the trachea, and if the disease was due to default of respiration there would be no tracheal ozæna. Besides, there is very often sinusitis complicating :zæna, and in that case what could re-education do?

Dr. Maru (Paris) had entrusted a large number of patients to For. They had not all benefited by the treatment: the majority were improved: sime were cured, in so far that they no longer had crusts or foetor. In some cases they had supplemented the treatment with injection of paraffin. In his opinion the double method-re-education and paraffin-seemer to he the best form of treatment.

Dr. R. For, in reply, said that at first sight the patients appeared to hreathe by the nose, but more critical examination showed that they lose the habit of nasal respiration. Obviously the method was one of massage, but it was continuous, since it was carried out by the patient. and herein lay the value of the procedure. The author thought that in tracheal ozæna there was also an insufficiency in thoracic respiration. He did not expect to cure patients with sinusitis; he had some failures. and attributed them to the fact that it had not been possible to re-establish nasal respiration.

Dr. JACQUes (Nancy) improved his patients by introducing a tampon if wool, thus preventing the access of air. By this simple treatment the crusting abates and fretor is much reduced. 


\title{
The Buccal Route as an Approach to the Peri-tonsillar Region and Maxillo-pharyngeal Space.
}

\author{
Br Dr. Gault (Dijon).
}

After removal of a lympho-sarcoma of the right tonsil by the buccal route in a man, aged thirty-two, the author carried out some anatomical and operative research of the peri-tonsillar region and maxillopharyngeal space. He concluded that (1) the peri-tonsillar region and maxillo-pharyngeal space are easily accessible by the buccal route provided that the anterior pillar be well drawn outwards by means of a lateral retractor, the patient being in Rose's position, the mouth widely open, and the region well illuminated by the frontal mirror. (2) The operation consists in making a vertical incision of the pharyngeal mucosa; retraction is then exercised outwards so as to expose the bony landmarks-inside the vertebral column, outside the styloid process, behind and outside the transverse process of the atlas. These are felt with the finger and probe. One then recognises the stylopharyngeus muscle and behind it the internal carotid. (3) This vessel can be ligatured or secured by forceps, and, if necessary, drawn outwards with the vagus and internal jugnlar vein by means of the lateral retractor, which enables the operator to work comfortably. (4) Intervention by the buccal route is relatively easy, and enables one to remove pharyngeal tumours, when not too extensive, without great mutilation. The difficulties of this method have always been exaggerated through fear of the internal carotid, although that vessel is really posterior and some distance off. To avoid it, one must recognise it. (5) This route is only contra-indicated in the case of too extensive growths with glandular involvement (sub-angulo-maxillary, parotid or inferior jugular). On the contrary, epithelioma in the early stage and certain primary lymphosarcomata, etc., of the naso-pharyngeal isthmus are amenable to this procedure. The mutilation is slight and the after-treatment particularly simple.

Dr. JACQUes (Nancy) was impressed with the benignity of the operation in old people and with the great facility of this ronte. Cancers are removed in an extremely easy manner by this method.

Dr. Luc (Paris) asked what form of anæsthesia M. Gault employed.

Dr. JACQUes (Nancy) arded that glandular involvement was rare in tumours of this region.

Dr. GAULT (Dijon) in reply, siad that he sometimes employed general anæsthesia and sometimes local. He also remarked that glandular infection was, upon the whole, rare in growths of this region, and some glands could be removed by the buccal route. Continual swabbing sufficerl to control hæmorrhage during the operation.

\section{Latero-pharyngeal Abscess of Otitic Origin.}

\author{
By Dr. Guisez (Paris).
}

The extension of auricular suppuration towards the pharynx is not of frequent occurrence, and only a few cases of it are on record. The author had occasion to operate on a child, aged two, for a very extensive lateropharyngeal phlegmon accompanying otitis. The abscess gave rise to asphyxiating srmptoms and had to be evacuater as a matter of urgency. Three days afterwards, as the temperature did not fall and the mastoid was very painful in its anterior third and apex, trephining was performed. 
It was then easy to see that necrosis was present, chiefly in the deep portion of the mastoid, the anterior wall of the meatus and the floor of the tympanum: the osseuns lesions extended deeply towards the pharyx. The hatero-pharyngeal phlegmon was therefore otitic in origin.

\section{Primary Tumours of the Trachea and Bronchi; Tracheo- bronchoscopic Diagnosis and Treatment.}

\section{By Dr. Guisez (Paris).}

The author bad hat the opportunity of diagnosing a certain number of primary tracheal growths, several of which he had been able to remove by the direct method. They comprised papillomata in children, polypi, frimary or secondary to trucheotomy wounds, intra-tracheal fibromati with their pedicles situated posteriorly, two cases of hernia of the posterior wall of the trachea, and enchondromata. These growths had caused the patients drspnoea with attacks of suffocation, and in some asphyxia had been imminent. Thanks to precision in diagnosis removal was effected per vias naturales. In the case of malignant tumours tracheoteopy decided the diagnosis and the time when tracheotomy would be required. Lastly, the author had been alle to make an early diagnosis ut eancer of the bronchus, which was verified by nicroscopical examination of a fragment removed by forceps, when neither the clinical aspect nor radiuscopy had permitted one to suspect the nature of the affection.

\section{Direct Posterior Rhinoscopy.}

By Dr. F. Laval (Touluuse).

The naso-pharynx, like the trachea and bronchi, can be clirectly rxplored. By the ease with which it may be employed, especially for acess to the lateral wall, direct rhinoscopy will render great services in tubal affections, and even in those of the tympanum, by enabling instrumental treatment to be carried out.

\section{Peri-øsophageal Phlegmon Following Extraction of a Foreign Body.}

\section{BY Dr. JAcques (Nalloy).}

The case related by the author showed that extration of a foreign hody per vias naturales, even when early and easy, does not exempt the patient from further contingencies.

An adult healthy man swallowed a fish-bone and experienced an exceedingly sharp pain in the inter-scapular region. Extraction of the foreign body by means of the tube was aceomplished without any diffi"ulty thirty-six hours afterwards. The fish-bone, very sharp, was fixed at the broncho-aortic segment of the asophagus. Some days later a periwoophageal phlegmon developed, characterised by an increasing" general malaise, furred tongue, lividity, thoracic wirlle jains, spasmodic comgh, anorexia, and absolute dysphayia. (Esopliagoscopy revealed a very narrow constriction just below the site previously oceupied by the foreign body. bordered by adematous folds of pale grer mucosa. Spontaneous evacuatlion of the abscess took place followed hy a ripid subsidence of all the alaming symptoms. Four coloured diagrams illustrated the cesophatgeal 
"ppearances of this complication, fortunately rare in the case of swallowed foreign bodies.

Dr. Guisez (Paris) had frequently observed abscesses resulting from foreign bodies. He thought that whenever odema is present it is advisable not only to remove the foreign body, but further, to make a small incision into the mucosa; one then sees a flow of pus. Abscesses are also observed as a result of operative measures for the removal of a foreign body-for example with Graefe's coin-catcher.

Dr. JACQues (Nancy) said that œesophagoscopy should be carried out by experienced hands. He had seen the pharyngeal mucosa rasped by the cesophagoscope.

$$
\text { H. Clayton Fox (trans.). }
$$

('To be continued.)

Alustriats.

\section{EAR.}

Mayer, Otto (Graz).- On Affections of the Auditory Nerve in Acquired Syphilis. "Arch. Internat. de Larrngol., d'Otol., et de Rhinol.," May-June. 1911.

The author has been struck by the number of cases reported by Finger in which " 606 " was emploved in the treatment of syphilis that hat been followed by lesions of the auditory nerve and untoward srmptoms attributed to affections of the anditory nerve. From the sixtr-five cases placed at his disposal untreated hi this remedr he has come to the following conclusions as to the occurrence of these labvrinth complications in this condition: (1) The affections of the auditory nerve may appear as early as three weeks after the chancre or six weeks from the period of inoculition. It is more frequent during the first six months but may crecur as late as thirty rears after. (2) In most cases the condition was ushered in by subjective noises and an absence of vertigo. (3) It is usually bilateral and frequently equal on both sides. It is rare for one ear to escape entirely. (4) While in almost half the cases there was a varving degree of vestibular involvement, in no case has he observed an isolated vestibular affection. Whereas the examination of the cases of Finger indicates preponderance of vestibular involvement, it would setem that the vestibular nerve is more sensitive to certain poisons by which the cochlear branch is little or hardly at all affected. A large number of cases may still fall to be considered in which the isolated infection of the vestibular apparatus has caused the case to pass unnoticed by the otologist into the hands of the neurologist. The author gives a new indication of the fact that affections of the auditory nerve may appear at all stages of syphilis, and that affections of the ear observed after the employment of arseno-benzol differ essentially from those due to syphilis.

J. D. Lithyou".

Buys (Brussels).- The Symptomatology of Labyrinth Lesions due to Indirect Traumatism. "Archives Internationales de Laryngologie, Otologie, et de Rhinologie," May-June, 1911.

Some of the above lesions improve; others get progressively worse. The apparent severity of the cranial injury is no index to that of the 